\title{
An Assessment of Solid Waste and Landfilis in Muscat Area, Oman
}

\author{
Alaa El-Zawahry, Abulbasher M. Shahalam, Ramzi Taha and Turki Al-Busaidi \\ Department of Civil Engineering, College of Engineering, P.O. Box 33, Sultan Qaboos \\ University, Al-Khod 123, Musca, Sultanate of Oman.
}

قيم الفضلات الصلبة والمرالمرفيمطاقة طقة بسللنةعملن

علاء الالولهري و لبو البشرشاه علام ورمزيطه وتركي البوسعيي

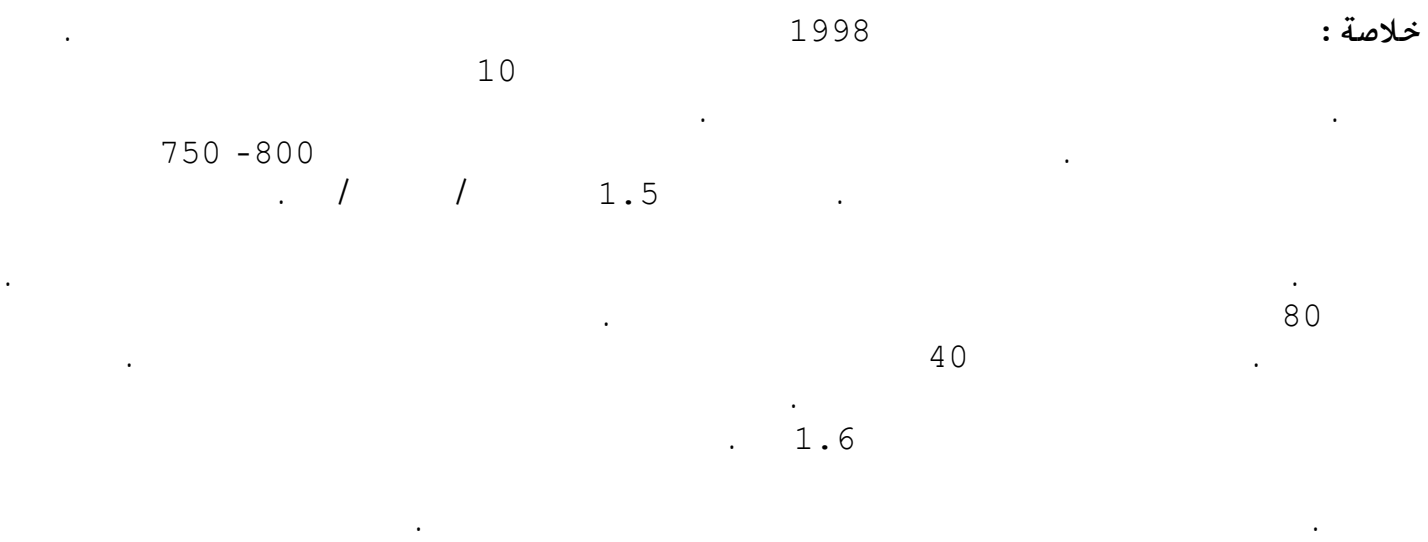

ABSTRACT: The paper presents the results of a 1998 study of the solid waste generation within the greater Muscat City area. The recent data were compared with the available data from the last 10 years to assess the solid waste problems within the area. Five operating landfills were used as the data collection points. It appeared that through the last decade, the solid waste generation rate has increased sharply. However, the rate of waste production stabilized to $750-800$ ton/day during the last three years of the $1990 \mathrm{~s}$. The rate amounts to $1.5 \mathrm{~kg} /$ person/day. Overall municipal waste volume decreased through the years while the amounts generated from private sources such as industries and commercial centers increased during the same period. This is due to the fact that the Sultanate of Oman is developing very fast with increasing industrial, commercial and residential activities. About $80 \%$ of the solid wastes is organic materials. This amount is high when compared to figures found in western countries. The data indicate that about 40 percent of the solid wastes are composed of recoverable materials. The concerned authorities should encourage the growth of industries to be involved in recycling business. Such activities will reduce the solid waste discharge in landfills and increase nearly 1.6 folds the expected life of existing landfills. A survey of the operating landfills indicate that the operational efficiency may be substantially improved by incorporating measures that deal with problems of gas production and leachate movements. The paper includes a detailed discussion of the problem and makes recommendations for possible future actions.

KEYWORDS: Solidwaste; Muscat; Generation; Composition; Disposal; Management; Recyling and Landfills.

\section{Introduction}

Muscat is the capital and most important city in the Sultanate of Oman. Modern residential, commercial and industrial developments have spread beyond its old capital limits into surrounding satellite townships connected with highways and modern utilities. Most of the 
developments are new and are founded on the newly found wealth of oil. As of the 1970s, the situation started to change drastically within the city, as was the case in other parts of the Sultanate. The country witnessed tremendous economic development including industrialization, urban sprawl and commercial activities. This unprecedented development known as the "Blessed Renaissance" started as His Majesty Sultan Qaboos assumed political power in the country. The urban area expanded from 15 to 4000 square kilometers (covers about $1.3 \%$ of the area of the Sultanate) during the last 28 years. The population of 56000 in 1970 has grown seven folds by 1988 and to about 10 folds by 1998. To manage the city, the administration is decentralized and divided into five geo-administrative areas (sub-municipalities). They are Greater Mutrah, Bousher, Al-Seeb, Al-Amerat and Quriyat. Based on estimated population figures of 1989 and 1993, the growth rates of the sub- municipalities are shown in Table 1 (Scheu, 1993).

Table 1: Population growth rate (1989-93) in sub- municipalities in Muscat.

\begin{tabular}{|l|l|l|c|l|}
\hline \multirow{2}{*}{ Sub-Municipalities } & \multicolumn{2}{|c|}{ Population } & $\begin{array}{l}\text { Growth Rate } \\
\text { \% Per yr }\end{array}$ & Density \\
\cline { 2 - 5 } & 1989 & 1993 & 2 & High \\
\hline Greater Mutrah & 156180 & 169000 & 7 & Medium \\
\hline Bousher & 102180 & 134000 & 7 & Low \\
\hline Al-Seeb & 103480 & 136000 & 7 & Low \\
\hline Al-Amerat & 23230 & 30000 & 4 & Low \\
\hline Quriyat & 19000 & 23000 & & \\
\hline
\end{tabular}

A literature review indicated that per capita solid waste generation stabilized by $1989 / 90$ to an amount of 1-1.5 kg/person/day (Mohammed, 1995), which was very much in-line with Arab world figure of $1 \mathrm{~kg} /$ person/day (Taufiq, 1992). Figure 1 depicts the solid waste production in Muscat area from1970 to 1994.

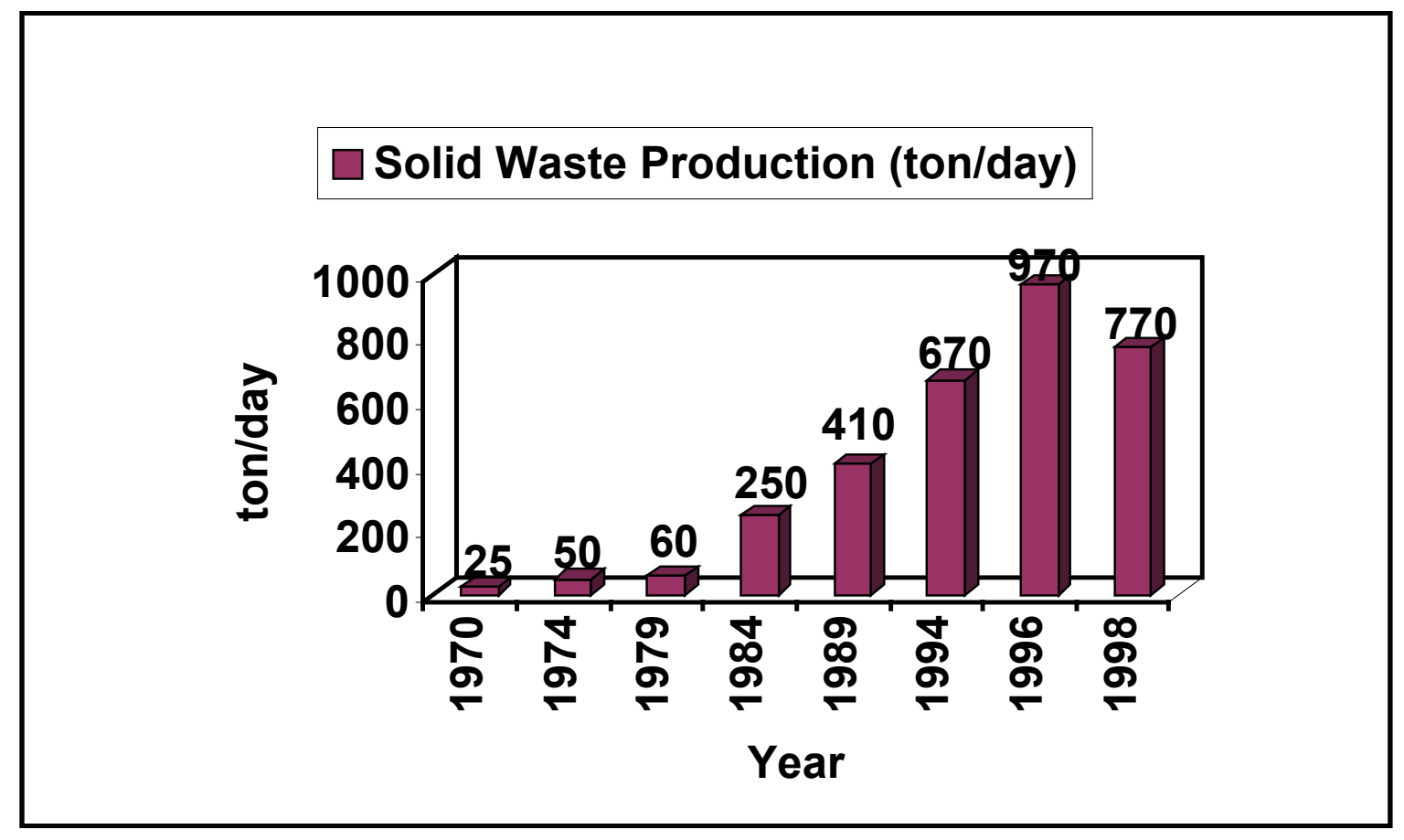

Figure 1. Solid waste production in Muscat (1970-1998).

The first landfill in Oman was introduced in Mutrah before 1970. At that time, it served the whole region, as it was the only landfill in the area. In the course of time, as the population grew, Muscat Municipality started operating five landfills including Mutrah. They are at Al-Seeb, 
Quriyat, Al-Amerat, Mutrah and Bousher (Al-Barami, 1999; Al-Lawati, 1998). No other disposal processes are practiced. The problem of solid waste needs to be addressed both from an engineering and scientific ways. The existing landfills are grown out of need and are mostly simple open landfills without proper design. Landfill problems are evident. A strategic plan for engineering management of solid waste in Muscat region is required. A study was carried out to determine the existing status of the region in terms of solid waste generation, its types and distribution. The data generated provide an invaluable baseline information for future development of effective and efficient management schemes for handling solid wastes in the region. The data collected in the study are used to delineate the dimension of solid waste problems in Muscat and they were used to forecast various possible outcomes and appropriate facilities capable of handling the problem.

\section{Study Approach}

Considering the limitation of resources and the scope of the study, it was decided to collect the solid waste data related to its composition and generation rate at the disposal site. Presently, there are five well-defined operating landfills within the Muscat Municipality. A visit through the city undoubtedly convinces the visitors that the city is kept quite clean of unattended solid wastes. In addition, a survey of solid waste at the source requires considerable resources of personnel, time and finance. The scope of the project was limited in all these aspects. However, it was the investigators' opinion that the possible error that may exist in data due to collecting data at the landfills is insignificant considering the large volume of wastes generated within the city.

At the landfill entrances, the number of discharging trucks, and the volume and weight of wastes were recorded at random checks. For the determination of waste composition, the waste separation and sorting was accomplished also at random choice of sampling.

\section{Data}

\subsection{Muscat City}

Analyses of 10 specific samples of $800-850 \mathrm{~kg}$ of solid wastes from various landfills taken at random points depict the averages shown in Table 2.

Table 2: Average components in an $825-\mathrm{kg}$ sample of solid wastes in Muscat area.

\begin{tabular}{|l|l|l|}
\hline Components & Weight in $\mathrm{kg}$ & \multicolumn{2}{c|}{$\%$} \\
\hline Food rests, vegetables and fruits & 320 & 38.8 \\
\hline Grass and trees rests & 103 & 12.5 \\
\hline Paper & 30 & 3.6 \\
\hline Cardboard & 105 & 12.7 \\
\hline Plastic & 70 & 8.5 \\
\hline Textiles & 36 & 4.4 \\
\hline Iron & 29 & 3.5 \\
\hline Wood & 20 & 2.4 \\
\hline Leather, Rubber & 4 & 0.5 \\
\hline Glass, Stones & 30 & 3.6 \\
\hline Rest & 78 & 9.5 \\
\hline Total & 825 & 100 \\
\hline
\end{tabular}

\subsection{Sub-Regions}

The sub-regions of the greater Muscat Municipality with respect to solid waste generation is more or less divided into five regions contributing to five landfill sites: Bousher, Al-Seeb, Mutrah, 


\section{EL-ZAWAHRY, SHAHALAM, RAMZI TAHA and AL-BUSAIDI}

Al-Amerat and Quriayat. In order to delineate the regional characteristics in the trend of solid wastes generation, the discharges in landfills were separately monitored for 12 weeks during December 1998 and January and February of 1999. Data of previous years were collected and compared with that of the present to establish the trends in solid wastes generation rates. Figures 2a and $2 \mathrm{~b}$ show two landfill sites at Bousher and Al-Seeb. These are typical sights in landfills in the city.

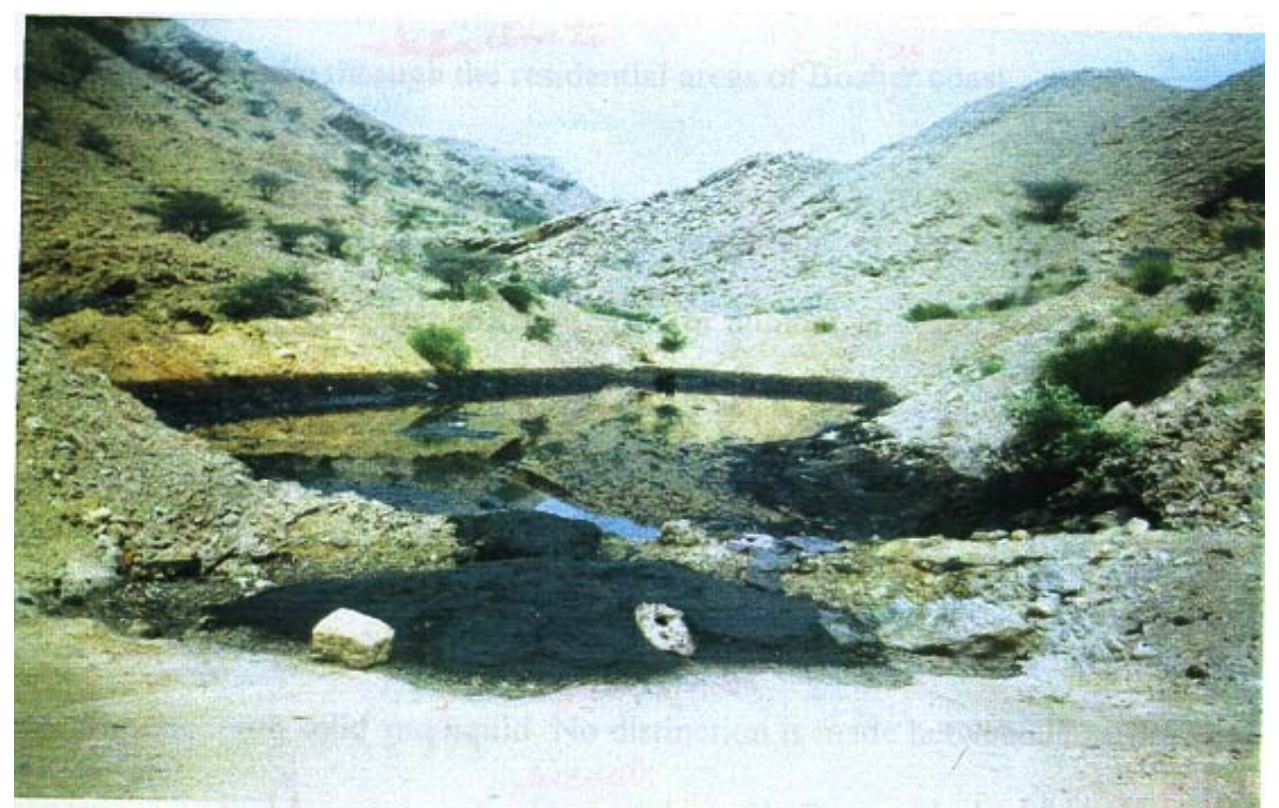

Figure 2a. Sludge disposal site at Boushar area.

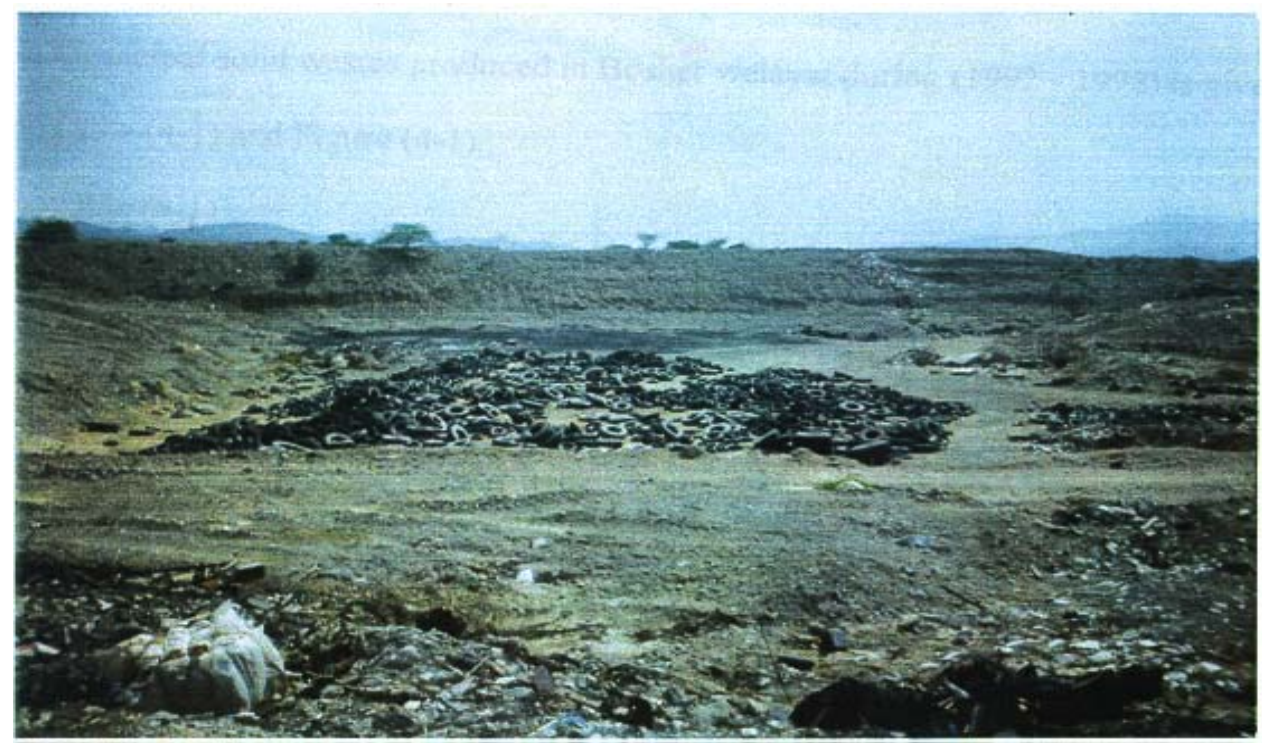

Figure 2b. Disposal of tires at Al-Seeb landfill.

\section{Bousher Landfills}

An-Sub landfill is located at the foot of the mountains behind the coastal plain in Bousher. It is near Ghala industrial area. The site has been in use since 1982. Usual practice is to segregate wastes into four main types for disposal purposes. They are: 1. General domestic and commercial wastes including light industrial and clinical wastes; 2 . Motor vehicles and bulky industrial wastes; 
3. Carcasses and slaughter house wastes, and 4. Sewage sludge. A trend of solid waste generation in Bousher area is shown in Figure 3.

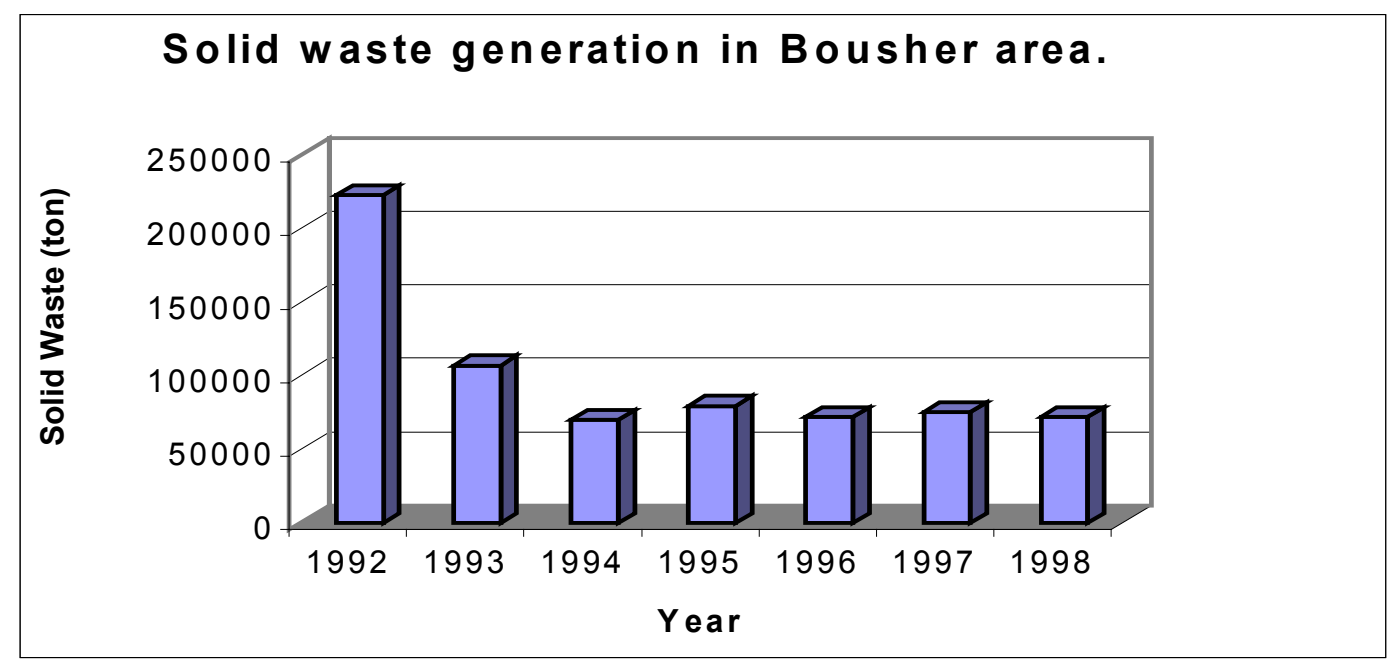

Figure 3. Trend of solid waste generation in Bousher area.

\subsection{Al-Seeb Landfills}

Al-Seeb Landfill is located at the north of Al-Seeb Wilayat, $14 \mathrm{~km}$ away from the center of the Municipality of Al-Seeb. The site has been in use for quite a number of years. The site is unmarked and occupies a gently undulating landscape. Nearby is Moubela Industrial City. It receives all types of solid wastes generated at the northern parts of Muscat City. Dispatched wastes are segregated into three separate categories: 1. Domestic and commercial, 2. Industrial and agriculture and 3. Liquid and semi-liquid (sludge) for separate disposal sites. Figure 4 shows the solid wastes generation trend in Al-Seeb landfill area for years 1992-1998.

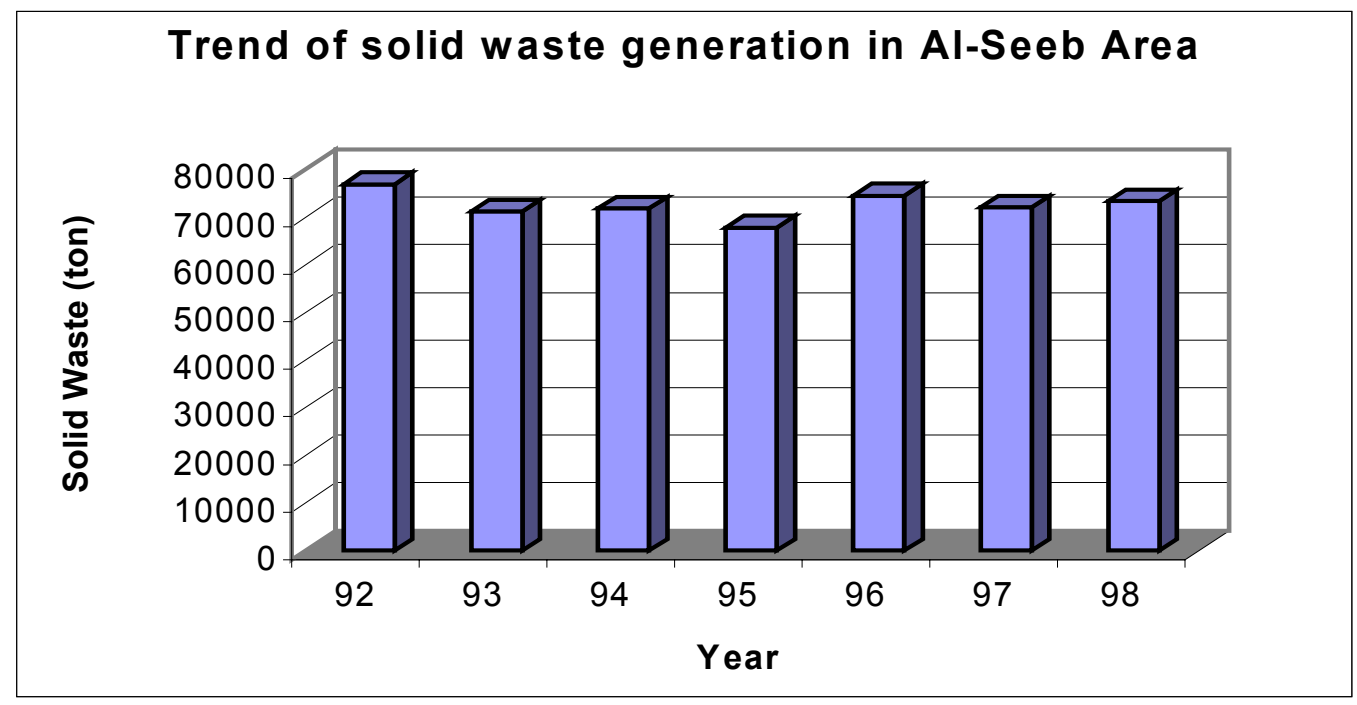

Figure 4. Trend of solid waste generation in Al-Seeb area.

\subsection{Mutrah landfills}

Mutrah landfill receives solid wastes from the old part of Muscat City. Figure 5 shows solid waste generation trend in Mutrah area for the years $1992-1998$. 


\subsection{Al'Amerat Landfills}

The trend of municipal solid waste generation (1992-1998) in Al-Amerat area is shown in Figure 6.

\subsection{Quriayat Landfills}

The trend of solid waste generation in Quriayat region is shown in Figure 7 for the years 19921998.

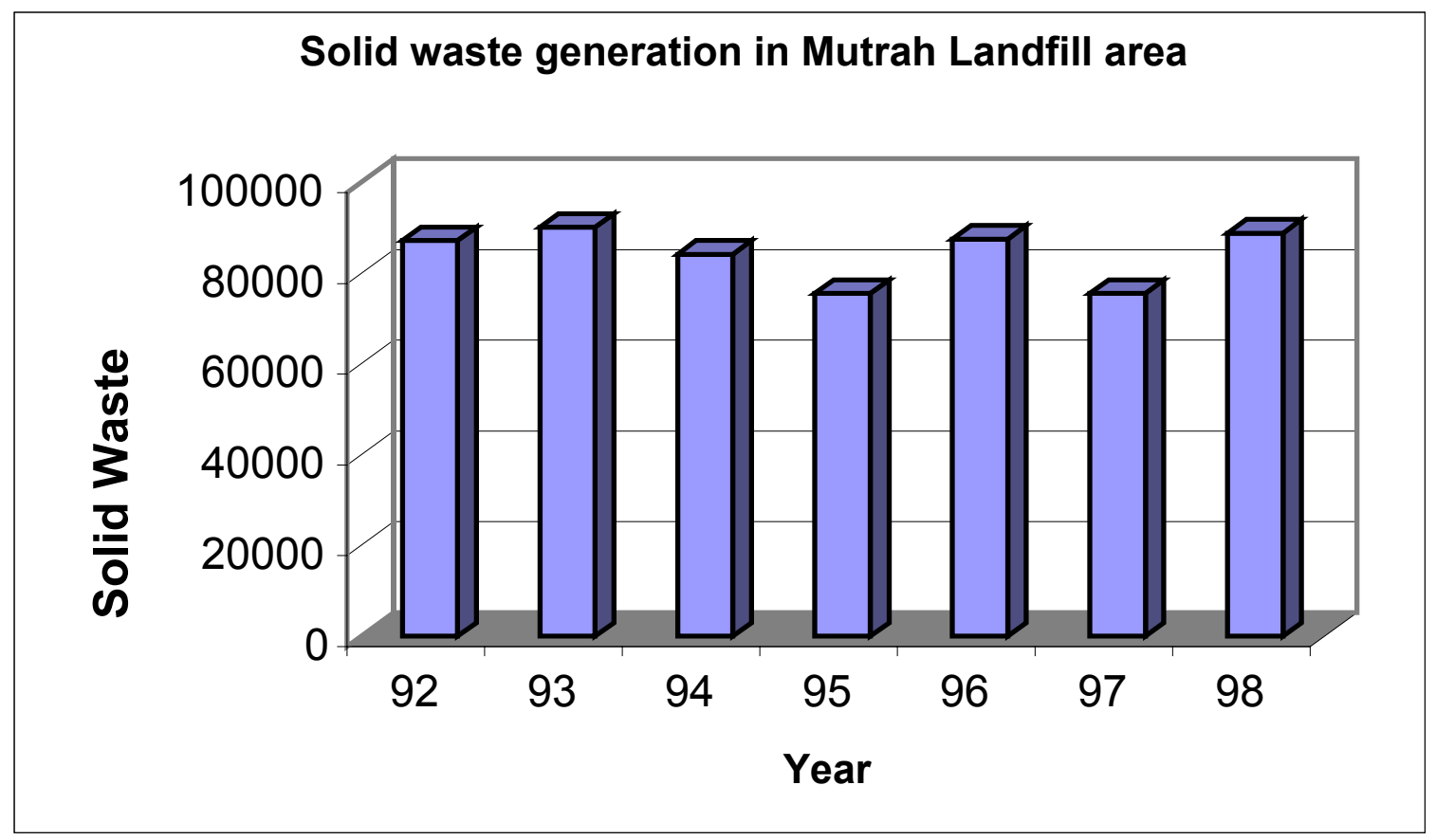

Figure 5. Trend of solid waste generation in Mutrah landfill area.

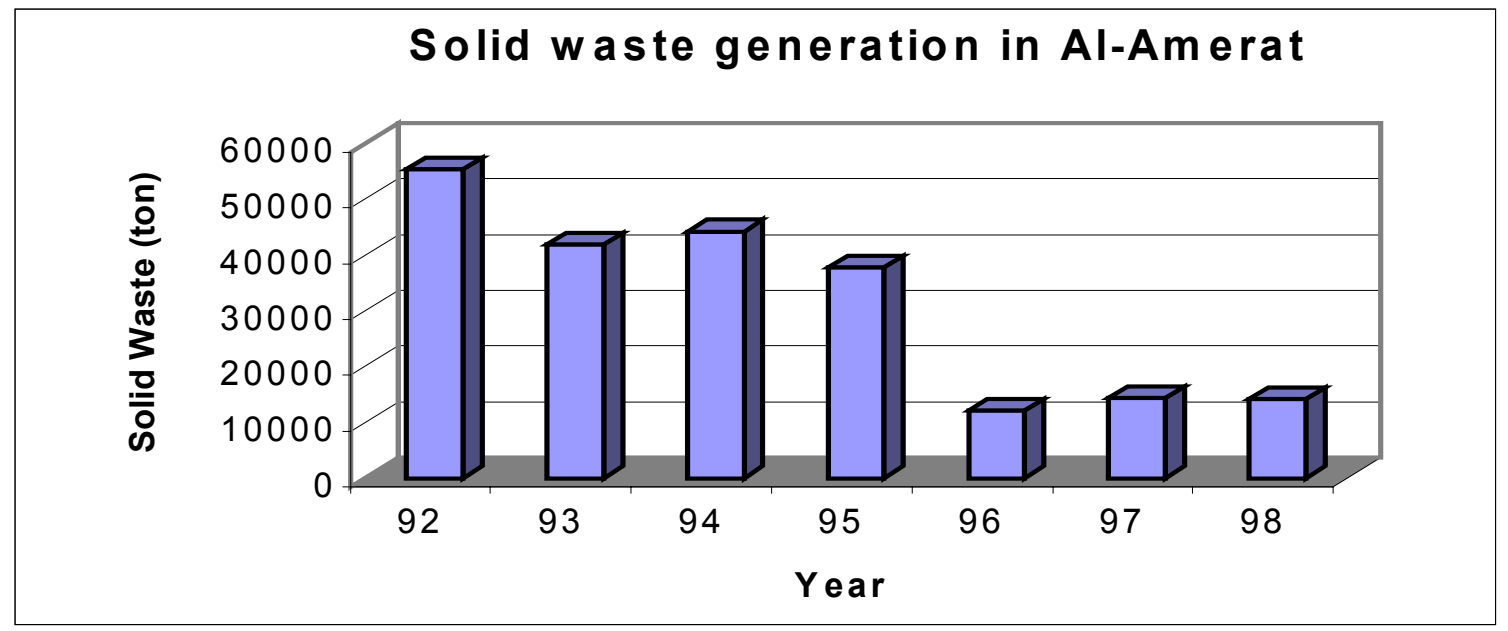

Figure 6. Trend of solid waste generation in Al-Amerat area.

\subsection{Municipal and Other Solid Wastes.}

During the study, an attempt was made to separate the wastes in two categories of municipal and other origin (private). Figures 8, 9 and 10 show the results of monitoring three landfills of AlAmerat, Bousher and Al-Seeb. Data of previous years are shown for comparison purposes. 


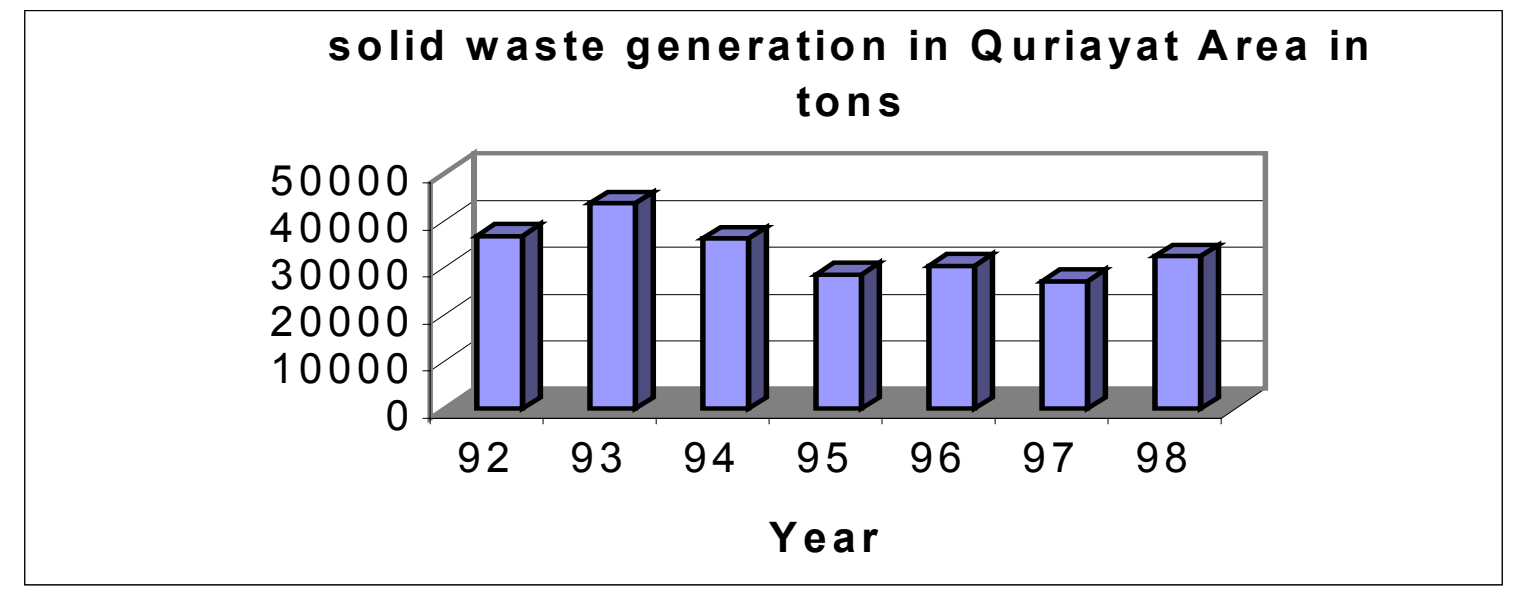

Figure 7. Trend of solid waste generation in Quriat area.

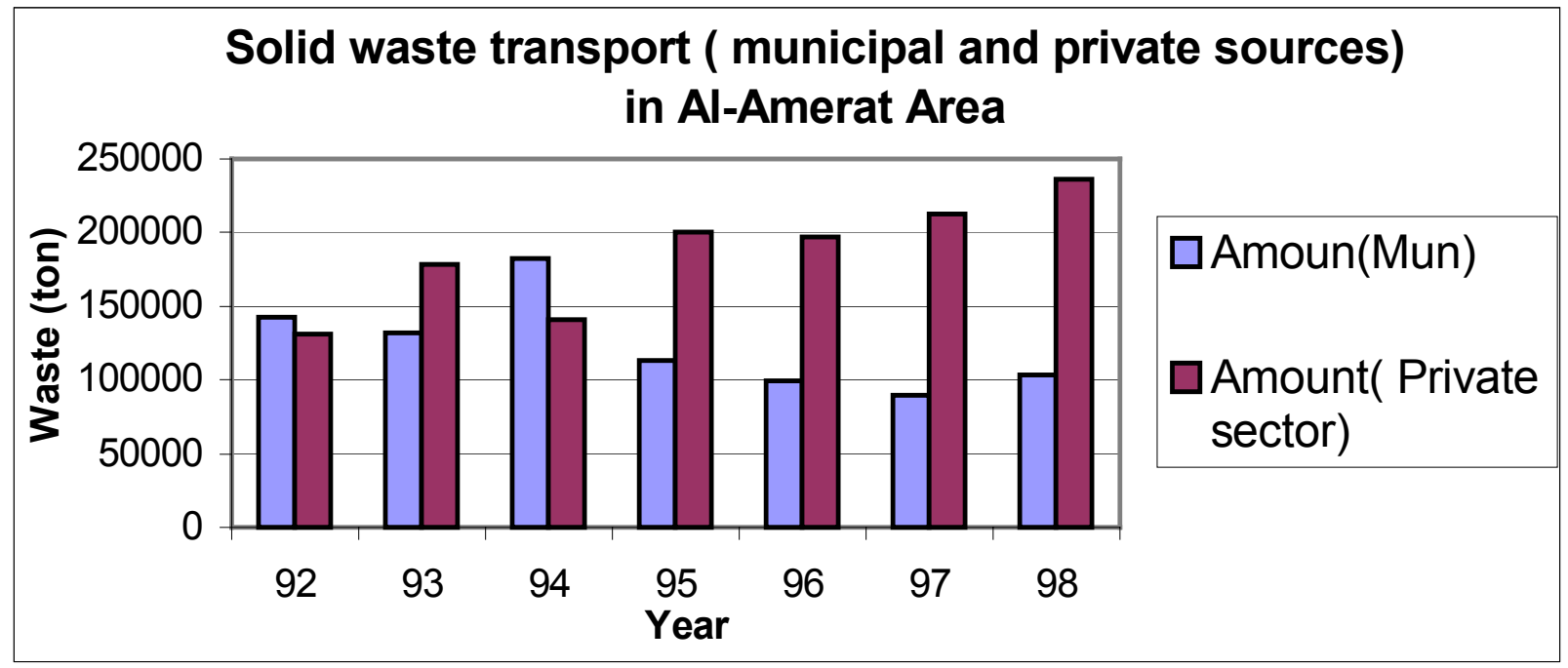

Figure 8. Solid waste from municipal and private sources in Al-Amerat area.

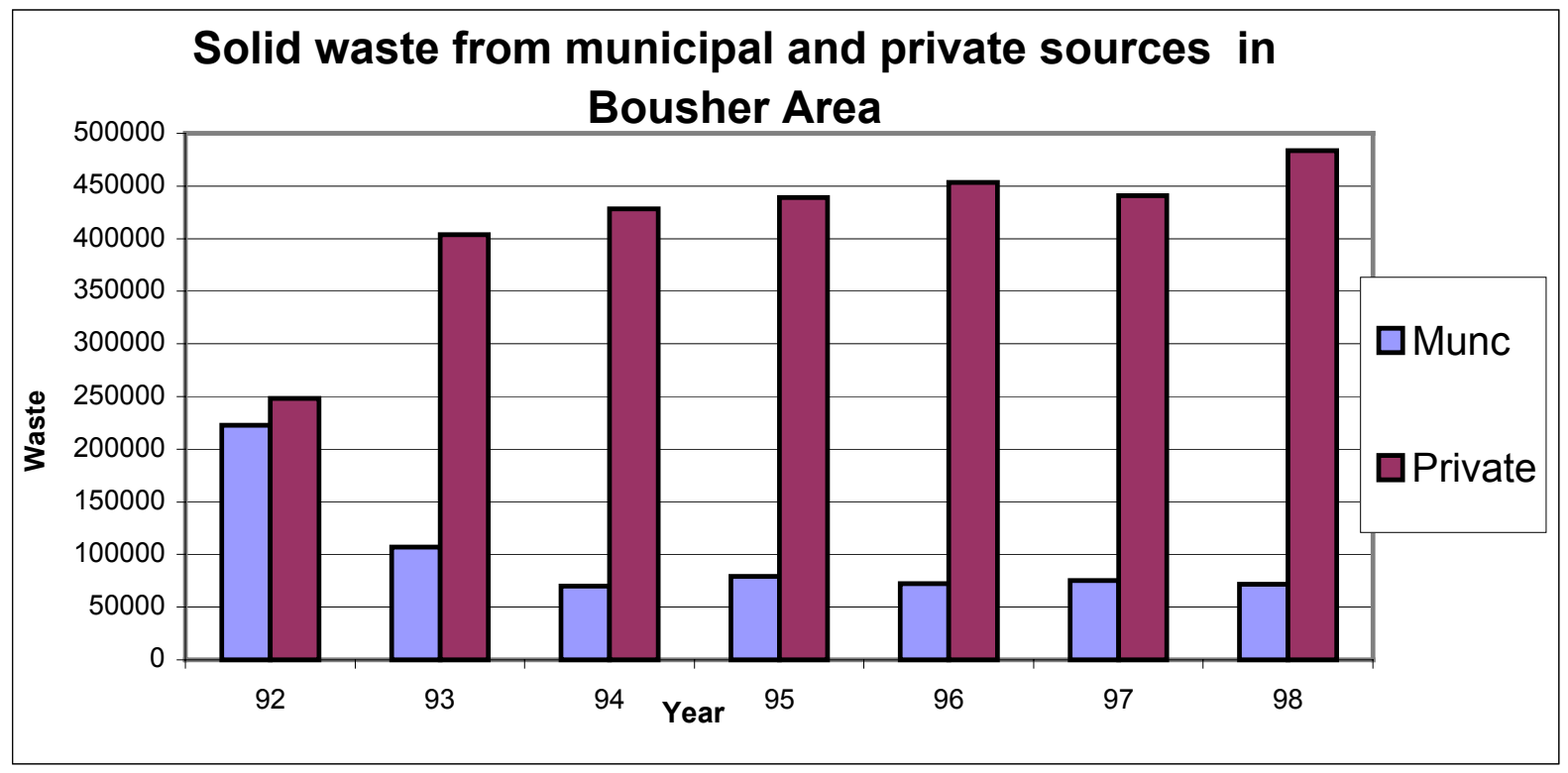

Figure 9. Solid waste from municipal and private sources in Bousher area 


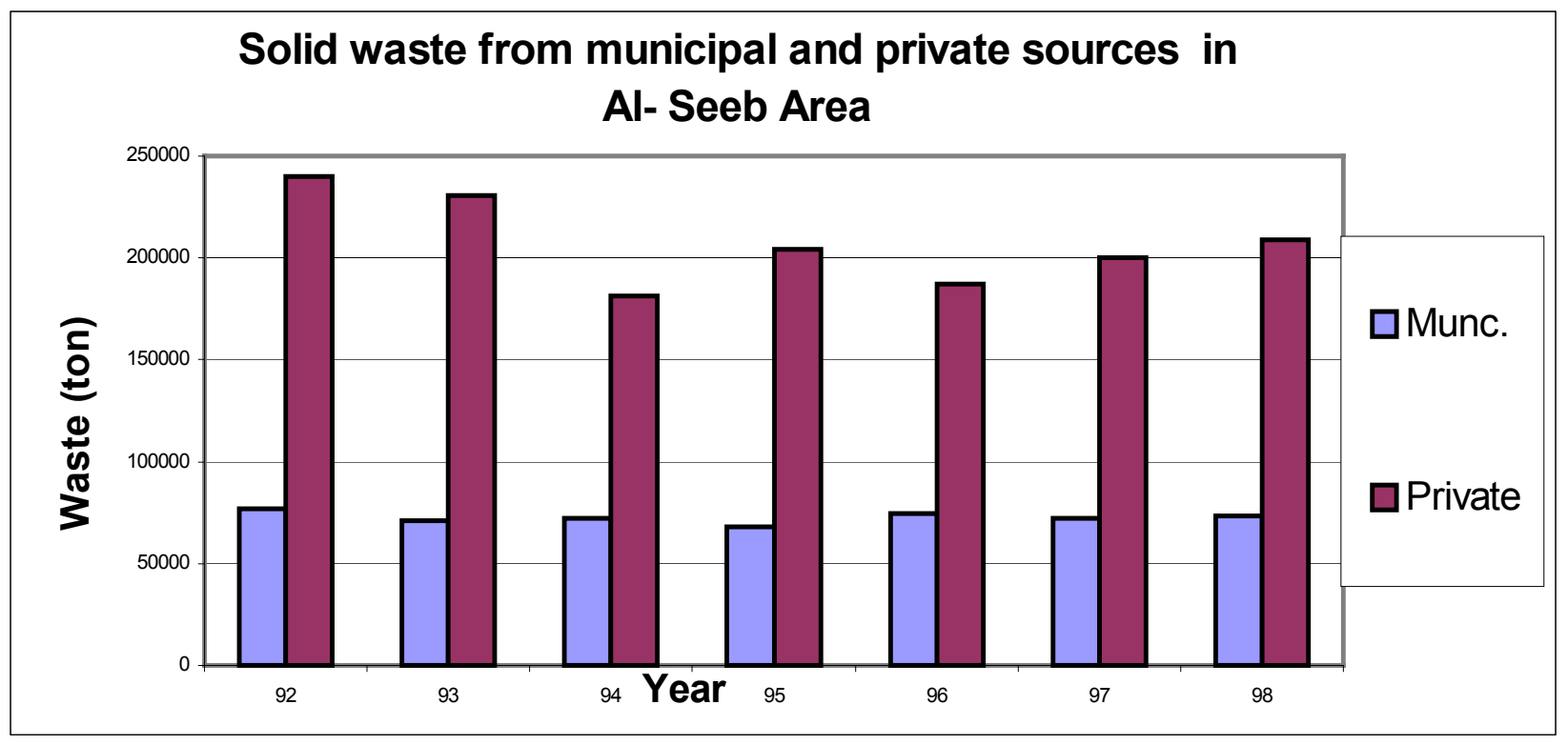

Figure 10. Solid waste from municipal and private sources in Al-Seeb area.

\section{Discussion}

\subsection{Composition of Solid Wastes}

Table 3 shows a comparison of compositions of solid wastes as they changed through time.

Table 3: Solid wastes composition 1993 and 1998 in Muscat vs. that of California, USA

\begin{tabular}{|l|l|l|l|}
\hline \multirow{2}{*}{ Composition } & \multicolumn{2}{|l|}{ Percentage } & California (Peavy,1987)1982 \\
\cline { 2 - 3 } & Oman & \\
\cline { 2 - 3 } & 1993 & 1998 & 27.4 \\
\hline Food Wastes & 49.8 & 38.8 & 28.5 \\
\hline Paper and Cartons & 17.5 & 16.3 & 10.3 \\
\hline Glass and Stones & 10.5 & 3.6 & 4.6 \\
\hline Plastics & 9.0 & 8.5 & 2.3 \\
\hline Textiles & 1.0 & 4.4 & 1.7 \\
\hline Leather and Rubber & Negligible & 0.5 & 1.2 \\
\hline Iron & 5 & 3.5 & 3.6 \\
\hline Wood & Negligible & 2.4 & 8.3 \\
\hline Aluminum & 0.6 & - & 12.1 \\
\hline Rest & 6.6 & 22.0 & \\
\hline
\end{tabular}

The data show significant changes in the content of food wastes. Eating habits of the population may be changing with time. Also modern packet and processed food supply greatly reduces the wastes. It is, however, expected that with time, this figure will stabilize to a lower value around 30 percent. Paper and cartons content is comparatively low. Glass and Stones content in 1998 dropped from that of 1993 considerably. It is anticipated that this is due mainly to stones fraction. Good up- keeping of the construction sites and regular road cleaning may have significant effects on this portion of the solid wastes.

\subsection{Solid Waste Generation}

Table 4 summarizes the solid waste generation rate in the greater Muscat City and the apparent solid waste generation in various regions based on the data of landfill discharges. One would 
expect a landfill discharge rate more or less equal to the actual generation rate provided the landfill capacities are adequate, and cross-regional transfer is not allowed. For example, in 1993, the total municipality generated nearly $2 \mathrm{~kg} /$ person/day. But the solid waste dumping rates in some of the landfills such as Al-Amerat and Quraiyat were about 2 and 3 times that of waste generation rate in the city. It is apparent that part of solid wastes generated at Mutrah and Al-Seeb was dumped in AlAmerat and Quraiyat landfills. However, from an observation of the city solid waste generation rate and discharge rates in various landfills in 1998, it is evident that the solid wastes are not transported in significant amount from one sub-region to another sub-region. This indicates better management, economic transport and stability in overall handling of the solid wastes within the municipal area.

Overall the solid waste generation rate within the city dropped from $2 \mathrm{~kg} / \mathrm{person} /$ day to 1.5 $\mathrm{kg} /$ person/day (Figure 1 and Table 4). The average solid-waste generation rate in the Arab word is within the range of $1-1.5 \mathrm{~kg} /$ person/day. Present rate hence appears to be stable and normal.

Table 4: Per capita solid waste in Muscat city and its sub-regions.

\begin{tabular}{|l|l|l|l|l|l|l|}
\hline \multirow{2}{*}{ Area } & \multicolumn{2}{l|l}{ Population } & \multicolumn{2}{l|}{$\begin{array}{l}\text { Solid wastes, } \\
\text { kg/day }\end{array}$} & \multicolumn{2}{l|}{$\begin{array}{l}\text { Per capita Solid } \\
\text { wastes } \mathrm{kg} / \mathrm{p} / \mathrm{d}\end{array}$} \\
\cline { 2 - 7 } & 1993 & 1998 & 1993 & 1998 & 1993 & 1998 \\
\hline Muscat (total City) & 492000 & 526417 & 970000 & 769000 & 2.0 & 1.5 \\
\hline Mutrah & 169000 & 177387 & 247000 & 243000 & 1.5 & 1.4 \\
\hline Bousher & 134000 & 115007 & 293000 & 197000 & 2.2 & 1.7 \\
\hline Al-Seeb & 136000 & 158064 & 195000 & 201000 & 1.4 & 1.3 \\
\hline Al-Amerat & 30000 & 40721 & 115000 & 39000 & 3.8 & 1.00 \\
\hline Quriyat & 23000 & 35238 & 120000 & 89000 & 5.2 & 2.5 \\
\hline
\end{tabular}

Recent yearly solid waste generation rates in five landfills (Figures 3, 4, 5, 6, and 7), when compared with those of the previous two years (1996 and 1997), are more or less unchanged. Such stable figures are extremely useful for developing an efficient solid waste management plan. However, it is a matter of concern that private sector contribution is increasing at a significant rate while municipal contribution is slightly decreasing or remaining more or less unchanged (Figures 8,9 and 10). From these figures, it might be inferred that the rates of Municipal contributions have attained a stable rate. The per capita production rate is expected to remain steady. However, similar predictions cannot be made for the private sector. It appears that the portion generated by the private sector is increasing. If the trend continues, the solid waste generated from the private sector may dominate the characteristics, volume and per capita waste generation in future years. It is probably the right time to study the industrial and commercial activities along with adoption and implementation of proper management techniques to relieve the landfills from disproportionate solid waste dumps. If appropriate, strict segregation policy for separation of industrial and commercial solid wastes from those of Municipal origin might be applied.

\section{Solid Waste Management}

The following management outline is apparently a viable, economical, and feasible approach towards a planned policy for handling solid wastes in the greater Muscat municipal area. It is presented here in a form of proposal and it is expected that design details and economical aspects of these proposals will be further studied in near future.

\subsection{Potential of Recycling of recoverable resources}

Recycling of recoverable solid wastes is not new in the Sultanate of Oman. Re-use of waste materials or their re-use by craftsman to produce utensils and other commodities has been practiced 
for a long period of time. Many workshops and craftsman depended for their products on recyclable wastes (e.g. Automobile parts, tires, metal sheets and aluminum scraps).

The economical renaissance that started in 1970 has given considerable growth in the consumption of consumer goods, which in turn produced a legacy of recyclable wastes. A recovery scheme for the recoverable materials will at first hand reduce the quantity of solid wastes disposed off into landfills. This will in turn bring also new industries, new jobs, and recovery of resources, which directly contributes to the economic condition of the country. It is noted from the trends in industrial countries of recognizing the need for controlled management of the recycling activities. In the United States, Germany and UK, the idea of using papers made of recyclable materials, and plastics made of recovered plastic scraps are commonly accepted.

An estimate of the potential recyclable items in solid wastes in greater Muscat area is shown in Table 5 .

Table 5: An estimate of potential recyclable solid wastes in Muscat area.

\begin{tabular}{|l|l|c|}
\hline Items & Possible reuse & Quantity ton / year \\
\hline Paper / cardboard / textiles / wood & Paper making & 65000 \\
\hline Plastics & Plastic container & 24000 \\
\hline Iron & Ingots of iron & 17000 \\
\hline Aluminum & Cans / files & 4000 \\
\hline Leather / Rubber & Shoes / Roads & 2000 \\
\hline
\end{tabular}

Recoverable materials account for about 40 percent of total yearly solid wastes of 280000 tons. Recovery of these materials reduces per capita solid waste discharge in landfills from 1.5 $\mathrm{kg} /$ day to $0.9 \mathrm{~kg} /$ day. Such a reduction in waste loads increases the expected operating life of landfills about 1.7 times.

Aluminum cans can generate an economic activity worth of RO 2,000,000 per year. The amount is derived using an RO 500/ton sale value.

For utilizing the total potential of paper related recoverable materials, it is anticipated that pulp and paper making industries may be encouraged locally to grow at small scale within capacities of 30-40 tons/day. Six such units may operate with available re-usable materials. Approximate capital investment necessary for such an endeavor is estimated to be about 9-10 million Omani Rials (Vogler, 1998). Nearly 600-700 people will be engaged in such industries producing $250 \mathrm{~kg}$ paper / person/day.

\subsection{Engineered Design and Management of the Landfills}

The existing landfills in the greater Muscat area are operating as open dumps without proper considerations to problems that may emanate from such waste disposal. The factors related to potential problems are landfill capacity, useful life, gas and leachate production and the potential of leachate contaminating the ground and groundwater.

Nearly $80 \%$ of the area solid wastes is organic materials (About $7 \%$ plastics, $60 \%$ rapid biodegradable materials and $12 \%$ normal biodegradable materials). Of the rapidly biodegradable materials, $75 \%$ is available for bio-degradation while out of the slowly biodegradable organic materials, $50 \%$ is available for bio-degradation. About $2000 \mathrm{~m}^{3}$ of gas is expected to be generated per day at $2.5 \mathrm{~m}^{3} /$ ton of solid wastes. In an engineering system, this gas may be recovered for economical use or safe discharge. Depending on the nature of the organic materials, the degradation process may continue from 5 to 15 years. The gas production continues through the degradation period.

The leachate production from solid wastes depends on several factors such as fill-height, rainfall, moisture content of solid wastes, field capacity (water) of solids and gas production. A sample of solid wastes from Bousher landfill shows an estimate of potential average leachate production to be $747 \mathrm{~kg} / \mathrm{m}^{2} / \mathrm{yr}$. The estimate is based on $2.5 \mathrm{~m}^{3} /$ ton/year of gas production, $15 \mathrm{~m}$ 
height of the fills and rainfall of $0.102 \mathrm{~m} /$ year. It is equivalent to nearly $47 \mathrm{1} / \mathrm{m}^{2}$. The amount is relatively small. However, it might end up in groundwater flowing as seepage through unprotected bottom of the landfills.

\section{Conclusions and Recommendations}

From the results of the limited study, the following conclusions and recommendations are drawn.

\subsection{Conclusions}

1. The Greater Muscat area produces nearly 770 tons/day of solid wastes. This is equivalent to producing $1.5 \mathrm{~kg} /$ person /day.

2. The data from 1989 to 1998 substantiate the observation that the solid waste production per year in the Greater Muscat City appears to be steady at nearly $750-800$ tons/day.

3. Nearly $80 \%$ of solid wastes is organic materials.

4. Out of the total 769 ton/day solid wastes, 112 tons comprise recyclable materials such as paper, cardboard, textile, wood, plastics, iron, aluminum, leather and rubber.

5. Potential rate of gas production from the solid wastes generated in Muscat area is about 2000 $\mathrm{m}^{3} /$ day.

6. Potential rate of leachate production in area landfills is about $7471 / \mathrm{m}^{2} / \mathrm{yr}$.

7. Area landfills needs to be redesigned and operated according to efficient and safe management policy.

\subsection{Recommendations}

1. A detailed study should be carried out to determine the basic factors necessary to design and operate the landfills safely, effectively and efficiently.

2. Design factors that need to be established are:

a. Water flow on surface and in soil near the existing landfills.

b. There are several items that need immediate attention. The items are proper landfill covers, gas collection or ventilation, leachate collection and containment systems, imperviousness of landfill bottom, leachate treatment, steps towards minimizing environmental and health risks.

\section{References}

AL-BARAMI, B.S. 1999. Solid Waste Management in Muscat Area, Final year Project, Department of Civil Engineering, Sultan Qaboos University, Oman.

AL-LAWATI, T., AL-KHUSHARI, Q. and MOHAMMED, M. 1998. Muscat Municipality. Personal communication.

MOHAMMED, O.O. 1995. Waste Management in the Sultanate of Oman, Friedrich Ebert Foundation, Amman, Jordan.

PEAVY, H.S., ROWE, D.R. and TECHOBANOGLOUS, G. 1987. Environmental Engineering, McGraw Hill, New York.

SCHEU, M. 1993. Assessment Study on Municipal Solid Waste Management in Muscat. Wetter, Germany: Kaltwasser-Engineering. 6-8.

TAUFIQ, M. A.V. 1992. Sustainable Development and the Environment in the Arab World. Tunis: Arab league Educational, Cultural and Scientific Organization (ALECSO), 87.

VOGLER, J. and SARJEANT, P. 1998. Understanding Small Scale Paper making, Aerlington, virginia, USA: Volunteers in Technical Assistance. 